\title{
Bavarian concerns about BM takeover
}

The acquisition of the Boehringer Mannheim Group for $\$ 11$ billion in cash is Hoffmann-La Roche's most expensive acquisition in its more than 100-year-old history. For Roche, with its assets of SFR 15 billion (US\$10.4 billion) and R\&D spending of SFR 2 billion (US $\$ 1.4$ billion) last year, this may be just another deal.

But for Boehringer Mannheim, "one of the shining stars in the German biotechnology arena," according to Germany's research minister, Jürgen Rüttgers, the implications are much wider.

There are jobs at stake, for a start. Boehringer runs three plants in Germany-one in Mannheim (around 6,500 employees), one in Penzberg $(2,027)$ and a third in Tutzing (429). The company accounts for $75 \%$ of all industrial biotechnology jobs in Germany, according to Bavarian ministry officials. The mass walkout by employees at Mannheim and Penzberg to demand job security after the acquisition was announced indicates that they feel threatened. After acquiring the California company Syntex in 1994, Roche dismissed 1,900 of 5,000 employees.

Boehringer Mannheim has been an exception within the German pharmaceutical and chemical industries. While companies like Hoechst (Frankfurt), Bayer (Leverkusen), BASF (Ludwigshafen), and Schering (Berlin) shifted R\&D or production plants to the US because of domestic political and public opposition to biotechnology in the 1980 s, Boehringer Mannheim stayed in Germany. In the autumn of 1996, it launched Rapilysin, a plasminogen activator to treat heart attacks, which was marketed as the first recombinant product isolated, developed, and "made in Germany." But how will the

Ingeborg Fürst is a freelance writer working in Munich.

ing revitalized, perhaps because of the growing number of companies exploiting the interface between diagnostics and therapeutics. Roche itself has coupled PCR-based diagnostics and its drugs in infectious diseases: Invirase for HIV, interferon- $\alpha$ for hepatitis $B$ and $C$, and Cytovene for cytomegalovirus. Abbott, the leader in diagnostics for HIV infections, has now developed Norvir to treat the disease. Glaxo Wellcome (London) and Roche are both developing drugs and diagnostics for influenza.

The new acquisition has also produced synergies. Boehringer Mannheim has two merger affect Boehringer Mannheim, the symbol of genetic engineering in Germany?

"Roche and Boehringer will be run as independent entities until the merger is okayed by the trust authorities [the European Commission (Brussels) and the Federal Trade Commission (Washington, DC)] in October or November this year," says Franz B. Humer, head of Roche's pharma division. That delay should provide plenty of time for rumor and discontent to foment.

Many projects are at stake, ranging from current investment and research alliances to the activities that stem from the BioRegio contest, Rüttgers' "big idea" for transforming Germany into a leading force in European biotechnology. The government maintains a confident front: "The new division 'Roche Boehringer Mannheim Diagnostics' will take up a leading position within the international biotech industry," Rüttgers claimed, "and will accelerate the development of biotechnology in Germany."

The official company line, too, is positive. "The merger can only have a favorable impact," says Jürgen Schwiezer, president of Boehringer Mannheim Deutschland. "Roche did not spent a fortune to just cut us into pieces."

A Boehringer Mannheim insider, however, reckons there will probably be substantial job losses in the therapeutic business, but not before the German parliamentary elections in spring 1998. Politicians are sensitive to the adverse effects of the current high unemployment rates on the electorate and would not want the Boehringer case to add fuel to the fire.

There are obvious synergies in research and production between the two companies, but their managements are making no commitments on the question of redundancies. "The due diligence has yet to be made," Humer says. "The most important objective is to bring together complementary parts of both firms to avoid the reinventing the wheel."

There are some positive signs for those in research and production at Boehringer Mannheim. Until the acquisition, Roche had no research facilities in Germany. "The timing of the takeover seemed good," says Jürgen Drews, head of Roche's global pharmaceutical research. "New attitudes toward genetic engineering can now mean that we benefit from Germany's scientific potential more than ever before."

Furthermore, over the past few years, Boehringer has invested DM1.5 billion (US\$880 million) in production plants in Penzberg and Tutzing, where the biotechnology diagnostics and therapeutic development operations are located. "The facilities in Penzberg will be extended to accommodate a new biotechnology production plant at a cost of DM180 million (US\$105 million), creating 150 more jobs," Schwiezer explains. Roche is particularly interested in the Tutzing and Penzberg facilities, says Schwiezer, because they will allow Roche to produce its own recombinant proteins, such as second-generation granulocyte colonystimulating factor on its own.

For the time being, Boehringer Mannheim will continue its development in gene therapy and genomics. Many of the research teams that were established at the end of June under the BioRegio initiative by the state of Bavaria, Boehringer Mannheim, and the Max-Planck-Institute of Biochemistry in Martinisried near Münich are dedicated to molecular medicine. And a new joint venture modeled along the lines of Molmed SPA, Boehringer Mannheim's joint venture with San Raffaele Biomedical Science Park in Milan, will be established in Germany within the next months. Like Molmed, it will be a service center offering cell processing and vector production for gene therapy under good manufactuing practice conditions.

Ingeborg Fürst

tests that determine the degree of tissue damage in heart attacks-Cardiac $\mathrm{T}$ and Trop T-and both Boehringer Mannheim and Roche have thrombolytic plasminogen activator drugs, Rapilsyn/Retavase and Activase, respectively.

Boehringer Mannheim Lab Diagnostics is the world leader in clinical chemistry, and a moderate player in immunoassays, a good synergistic fit with Roche and its PCR technology, according to Lloyd-Harris. Moreover, Boehringer Mannheim's investment in electrochemiluminescence for immunoassays, a technology licensed from Igen (Rockville, MD), will also provide a platform for integration with clinical chemistry, and again complements PCR.

In addition to pairing diagnostics and therapeutics for near-term use, Roche recognizes the role that pharmacogenetics will play in the future in diagnosing and treating disease. Diagnosis by examining a patient's genotype will enable more successful treatment, as it will help determine which drugs work best in which individuals. With its combined portfolio of diagnostics, Roche-Boehringer Mannheim is well positioned to capitalize on the trend toward pharmacogenetic diagnosis.

Vicki Brower 